\title{
HYPOPHYSECTOMY OF THE IMMATURE GUINEA-PIG AND THE OVARIAN RESPONSE TO GONADOTROPHINS
}

\author{
J. S. PERRY AND I. W. ROWLANDS \\ A.R.C. Institute of Animal Physiology, Babraham, Cambridge, and The Zoological \\ Society of London, Regent's Park, London, N.W.1
}

(Received 17th May 1963)

\begin{abstract}
Summary. A $50 \%$ decrease in ovarian weight occurred within 4 to 6 days after hypophysectomy, accompanied by a gradual reduction in the total number of normal vesicular follicles and the disappearance of all the largest follicles. There was an initial accumulation of atretic follicles followed by a reduction in their numbers as they became absorbed in the ovarian stroma.

Attempts to induce follicular stimulation to a degree which was adequate for ovulation and corpus luteum formation were unsuccessful. A constant feature of the ovarian response to gonadotrophins from a variety of sources consisted of a 'luteinization' of atretic follicles and stromal tissue.
\end{abstract}

\section{INTRODUCTION}

Relatively few accounts have been given of the action of gonadotrophins on the ovary of the guinea-pig. Those of Aron (1932), Loeb (1932), Guyénot, Held \& Ponse (1939) and Guyénot \& Held (1941) have been summarized and compared by Hamburger \& Pedersen-Bjergaard (1946) who themselves made a detailed quantitative study of the reactivity of the guinea-pig ovary to a variety of these substances. As far as we have been able to ascertain, however, only Guyénot et al. (1939) and Guyénot \& Held (1941) have carried out investigations of this sort using hypophysectomized guinea-pigs. In the former paper, an extract of urine of ovariectomized women was found to have only a folliclestimulating effect on the ovaries. In the second paper, the consecutive action of this substance and chorionic gonadotrophin (CG) was examined in two hypophysectomized guinea-pigs. One of these animals died on the 2nd day of treatment with $\mathrm{CG}$, and the large follicles resulting from the first part of the treatment were already showing signs of luteinization and thecal hypertrophy. The second animal was killed 1 day after a week's treatment with CG. The ovaries were greatly enlarged and contained many heavily luteinized follicles which had formed corpora lutea or pseudo-corpora lutea ('meroxanthosomes') but there was no mention of the occurrence of ovulation. The ovarian response in the immature guinea-pig to $\mathrm{CG}$ without previous treatment with pregnant mares' serum, was shown by Freed \& Coppack (1936) to consist of thecal luteinization in follicles with or without an antrum and it was considered by these authors to be essentially similar to that in the immature rat. 
The aim of the present work was to find a method of inducing follicular growth and ovulation in the hypophysectomized immature guinea-pig in order to compare the corpus luteum so formed with that produced in the intact guinea-pig. A necessary preliminary to this study was a quantitative investigation of the effects of hypophysectomy on the ovary, and the results obtained form the first part of this paper. The action of a variety of gonadotrophins was then investigated, but we have not obtained a degree of follicular stimulation adequate for the induction of ovulation and the formation of corpora lutea. Thus we have not been able to confirm the observations of the Swiss workers, referred to above, with respect to the hypophysectomized animal. On the contrary, we have found the ovarian follicles of the hypophysectomized guineapig to be extremely refractory to stimulation by exogenous gonadotrophins, and most of the preparations we have used have had a luteinizing effect on the ovary, involving the theca interna and, to a varying degree, the stromal tissue.

\section{MATERIALS AND METHODS}

ANIMALS

The animals used in these experiments were drawn from a colony of albino guinea-pigs of the M.R.C. strain and were maintained on a diet of SG 1, green food and hay. All were immature, 3 to 4 weeks old and between 200 and $300 \mathrm{~g}$ in weight. All body weights were recorded after an overnight fast.

\section{HYPOPHYSEGTOMY}

Anaesthesia was induced by the method described by Rowlands (1961) and the operative techniques, including that of tracheotomy, closely followed those of McPhail \& Parkes (1933). The approach to the basisphenoid, the drilling and the removal of the gland were identical to the previous methods. The tracheal cannula, however, was a short-bevelled hypodermic needle bent into a U-shape as was used by Good, Ely, Heiselt, Done \& Keeley (1956). A plug of gelatin sponge (Sterispon) was placed in the drill-hole and a thin patch of the same substance was used to seal the incision in the trachea, after the removal of the cannula. The pituitary gland was sucked out through a collecting flask in which it was usually possible to identify the anterior and posterior lobes and to estimate roughly the completeness of the removal.

All the animals recovered quickly from anaesthesia. They were given by mouth $6 \mathrm{mg}$ of Cortisol acetate and $250 \mathrm{mg}$ glucose twice daily for 2 weeks after operation as recommended by Brooks, Glayton \& Worden (1959). A supply of water containing glucose was provided as well as tapwater, but the supply of tomato juice, recommended by Brooks et al. (1959) was discontinued. Usually the animals remained in a listless condition for a period of 12 to 14 days after operation; they had a staring coat and poor appetite and nearly every one lost weight. They then regained normal appetite and soon afterwards they became almost indistinguishable from normal animals.

A proportion of the animals which were allowed to survive for longer than 1 
week after hypophysectomy, developed an intestinal obstruction with compaction of caecal contents leading eventually to peritonitis and death. In a small number of these animals, the caecum was found perforated. It seems probable that the condition was the result of hypothalamic damage due to excessive traction on the pituitary stalk when suction was applied.

\section{GONADOTROPHINS}

The following were given by subcutaneous injection:

Serum gonadotrophin (PMS). A freeze-dried preparation (Boots', Veterinary) containing 100 i.u./ml.

Human menopausal gonadotrophin (нмG). A preparation, HMG 20, was used; it was stated to have double the potency of the HMG standard.

Human pituitary extract. A preparation, CP 1 (Butt, Crooke, Cunningham \& Wolf (1963)) was used which was said to be 1000 times as active as the HMG standard preparation. This material and HMG 20 were kindly given by $\mathrm{Dr}$ W. R. Butt.

Sheep pituitary extract. A small sample was made available by Dr R. V. Short. Horse pituitary extract. Two preparations AP $118 \mathrm{~B}$ and a sample prepared by the McShan method, were both made available through Dr G. E. Adams.

Guinea-pig pituitary extract. Aqueous alkaline extracts of acetone-desiccated glands from males and hysterectomized animals. The doses of the preparation are stated in Tables, 3, 4 and 5 .

\section{AUTOPSY PROCEDURE}

The animals were killed with chloroform, and the ovaries, reproductive tract, adrenal and thyroid glands were fixed in Bouin's fluid and afterwards weighed. The skull was opened and the sella turcica examined for pituitary remnants. If there was doubt about the completeness of the hypophysectomy, the skull was fixed in formol saline solution and the basal region was later removed and decalcified in formic acid, and serial sections were made. If surviving pituitary tissue was identified in the sections the animal was discarded from the test.

\section{HISTOLOGY}

Sections of the ovaries were cut at $5 \mu$, and every tenth section mounted and stained in haematoxylin and eosin. The position of each vesicular follicle was marked on the coverglass with Gurr's glass-marking colour and follicular diameter was calculated from the mean of two diameters at right angles, measured on the section in which the follicle appeared largest.

Individual follicles were classified as normal or 'atretic', the latter term referring to degenerative changes in the follicular cells or the oocyte. The degenerative changes resemble those which normally occur in the ovaries of intact guinea-pigs, as described by Stafford, Collins \& Mossman (1942). In general, atresia was easily detected by changes beginning with pycnosis of some of the granulosa cells, usually those in the vicinity of the discus proligerus. 
Whether or not these changes were preceded by degeneration of the oocyte was uncertain, but at least they afford a criterion by which an individual follicle can confidently be classified. The granulosa cells of the follicles which enlarged after treatment with gonadotrophin were loosely packed, but not obviously abnormal; these follicles were classified as 'atretic' only when the oocyte was found to be grossly abnormal.

\section{RESULTS}

\section{CHANGES FOLLOWING HYPOPHYSECTOMY}

\section{Quantitative}

The observations, given in Table 1 , show that the relative weight of the ovaries was reduced by about $50 \%$ in 4 to 6 days after hypophysectomy, after which there was little evidence of any further reduction in the size of the ovaries. There was a slight reduction in the relative weight of the uterus, but that of the thyroid and the adrenal glands does not seem to be affected by the operation.

TABLE 1

EFFECT OF HYPOPHYSECTOMY ON BODY WEIGHT AND ON FIXED WEIGHT OF REPRODUCTIVE AND ENDOCRINE ORGANS

\begin{tabular}{c|c|c|c|c|c|c|c}
\hline \multirow{2}{*}{$\begin{array}{c}\text { Time after } \\
\text { operation } \\
\text { (days) }\end{array}$} & \multirow{2}{*}{ No. animals } & \multicolumn{2}{|c|}{ Mean body weight $(\mathrm{g})$ at: } & \multicolumn{4}{|c}{ Mean weight $(\mathrm{mg} / 100 \mathrm{~g})$ of: } \\
\cline { 2 - 5 } \cline { 5 - 8 } & & Operation & Autopsy & Ovaries & Uterus & Thyroids & Adrenals \\
\hline 0 & 4 & - & 235 & $20 \cdot 6$ & $44 \cdot 7$ & $9 \cdot 5$ & $37 \cdot 2$ \\
3 & 4 & 288 & 255 & $15 \cdot 0$ & $56 \cdot 6$ & $9 \cdot 9$ & $34 \cdot 7$ \\
4 & 3 & 200 & 165 & $11 \cdot 0$ & 32.5 & $8 \cdot 1$ & $38 \cdot 9$ \\
6 & 4 & 257 & 252 & $10 \cdot 3$ & $39 \cdot 4$ & $8 \cdot 3$ & $36 \cdot 0$ \\
14 to 16 & 3 & 257 & 278 & $10 \cdot 0$ & $36 \cdot 1$ & $8 \cdot 9$ & $32 \cdot 2$ \\
35 & 1 & 300 & 283 & $6 \cdot 0$ & $34 \cdot 0$ & $6 \cdot 7$ & $29 \cdot 7$ \\
\hline
\end{tabular}

Histological changes in the ovary and uterus

In the intact immature guinea-pig the follicles acquire an antrum when they reach a diameter of about $150 \mu$ and in the three control animals which have been studied in detail (see Text-fig. 1 and Table 2) slightly more than half of the normal vesicular follicles were between $200 \mu$ and $275 \mu$. The largest follicles measured about $800 \mu$ but they comprised fewer than $1 \%$ of the total number of normal vesicular follicles in the ovaries. Table 2 shows that $27 \%$ of all the vesicular follicles in these three intact immature guinea-pigs were atretic. This proportion does not include those in which atresia was so far advanced that the outline of the structure was indistinct and difficult to measure; thus many which would fall within the smallest size-groups in Text-fig. 1 are excluded.

Hypophysectomy does not initiate histological changes which differ in kind from any which can be seen in the ovaries of intact guinea-pigs, but it intensifies the incidence of follicular atresia, and eventually eliminates all the larger vesicular follicles. It can be seen from Text-fig. 1 that all the larger follicles 
have disappeared by the 3rd day, and there remain very few normal ones over $400 \mu$ in diameter. By this time the proportion of atretic follicles has more than doubled (from $27 \%$ to $59 \%$ ), but Text-fig. 1 fails to indicate an obvious rise in the number of the large follicles in this condition. Only one of the three animals killed on the 4th day after hypophysectomy had any normal vesicular follicles;

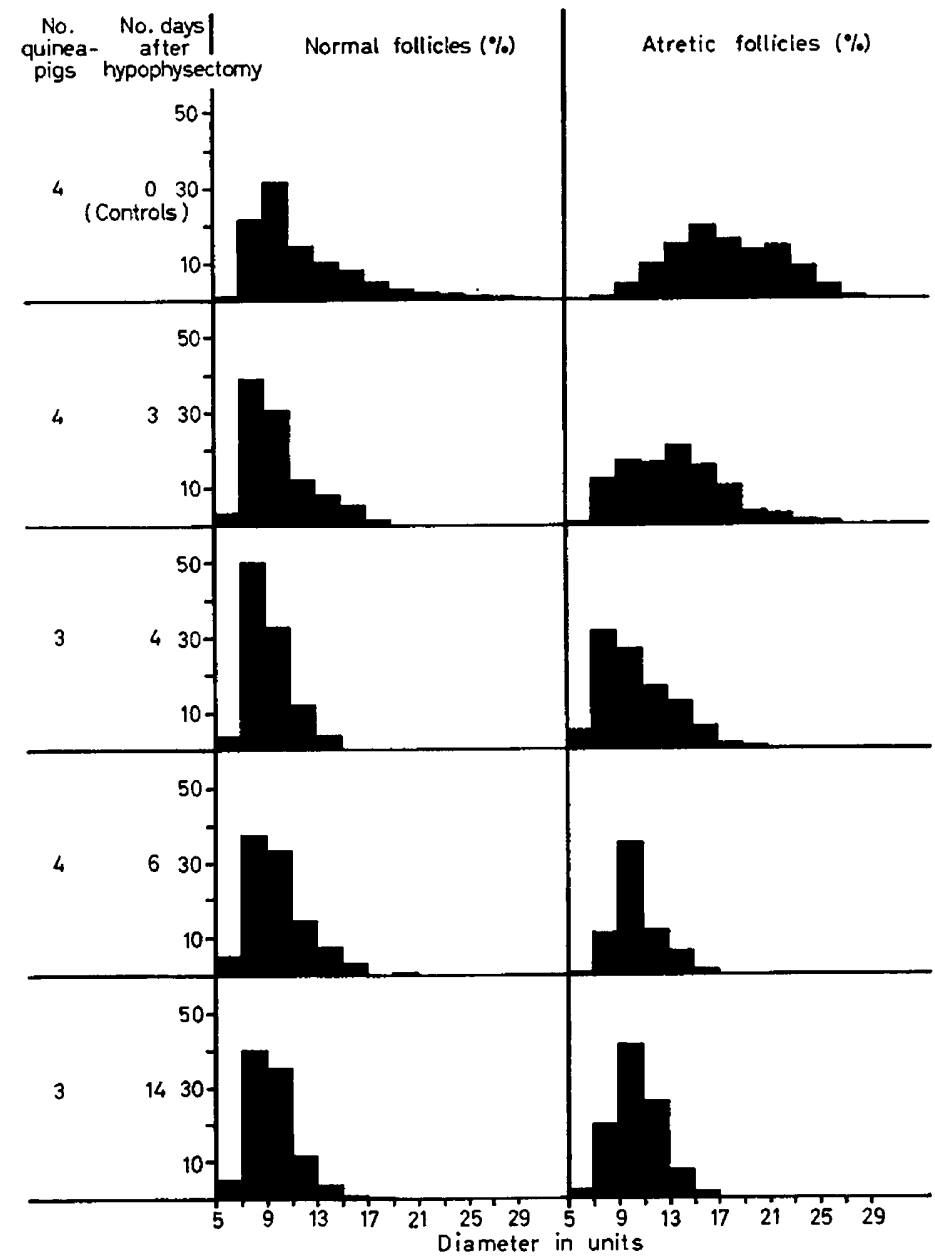

Text-Fig. 1. Proportion of normal and atretic follicles of different diameter in the ovaries of immature guinea-pigs from 0 to 14 days after hypophysectomy. The measurement is expressed in units, one unit being equal to $27.5 \mu$. The size-interval between follicles in adjacent columns is, therefore, $55 \mu$, the smallest and largest follicles measured being $137.5 \mu$ and $797.5 \mu$, respectively; in practice, a range of 140 to $800 \mu$.

the largest measured $385 \mu$. In the other two animals of this group all the follicles that had developed beyond the primordial stage were atretic.

Very little difference could be discerned between the ovaries of three guineapigs killed 6 days and those of two killed 14 days after hypophysectomy. In these five animals the number of normal vesicular follicles had increased greatly and the proportion which were atretic was reduced to about $36 \%$. The 
largest normal follicles in these ovaries were $500 \mu$ in diameter, but the proportion of these was negligible.

The ovaries of two guinea-pigs killed respectively 16 and 35 days after hypophysectomy did not contain any vesicular follicles.

The overall picture suggests, therefore, that the number of normal vesicular follicles is gradually reduced after hypophysectomy and that their production may eventually cease. There is an initial accumulation of atretic follicles

TABLE 2

EFFECT OF HYPOPHYSEGTOMY ON THE NUMBER AND SIZE OF NORMAL (VESICULAR) AND ATRETIC FOLLIGLES

\begin{tabular}{|c|c|c|c|c|c|c|}
\hline \multirow{2}{*}{$\begin{array}{l}\text { Guinea-pig } \\
\text { No. }\end{array}$} & \multirow{2}{*}{$\begin{array}{c}\text { Time after hypo- } \\
\text { physectomy (days) }\end{array}$} & \multicolumn{3}{|c|}{ No. vesicular follicles } & \multicolumn{2}{|c|}{$\begin{array}{c}\text { Mean diameter of follicles } \\
(\mathrm{mm})\end{array}$} \\
\hline & & Normal & Atretic & $\begin{array}{c}\text { Normal } \\
(\%)\end{array}$ & Normal & Atretic \\
\hline \multirow[t]{2}{*}{$\begin{array}{c}39 \\
112 \mathrm{~N} \\
113 \mathrm{~N}\end{array}$} & $\begin{array}{l}0 \\
0 \\
0\end{array}$ & $\begin{array}{l}281 \\
249 \\
189\end{array}$ & $\begin{array}{r}126 \\
66 \\
74\end{array}$ & $\begin{array}{l}69 \\
79 \\
72\end{array}$ & $\begin{array}{l}0.316 \\
0.323 \\
0.378\end{array}$ & $\begin{array}{l}0.481 \\
0.492 \\
0.476\end{array}$ \\
\hline & & 719 & 266 & 73 & & \\
\hline \multirow[t]{2}{*}{$\begin{array}{l}40 \\
41 \\
42 \\
51\end{array}$} & $\begin{array}{l}3 \\
3 \\
3 \\
3\end{array}$ & $\begin{array}{r}158 \\
82 \\
83 \\
152\end{array}$ & $\begin{array}{r}88 \\
48 \\
314 \\
232\end{array}$ & $\begin{array}{l}64 \\
63 \\
21 \\
40\end{array}$ & $\begin{array}{l}0.291 \\
0.305 \\
0.233 \\
0.248\end{array}$ & $\begin{array}{l}0.409 \\
0.414 \\
0.358 \\
0.339\end{array}$ \\
\hline & & 475 & 682 & 41 & & \\
\hline \multirow[t]{2}{*}{$\begin{array}{l}66 \\
85 \\
99\end{array}$} & $\begin{array}{l}4 \\
4 \\
4\end{array}$ & $\begin{array}{r}88 \\
0 \\
0\end{array}$ & $\begin{array}{r}54 \\
324 \\
184\end{array}$ & $\begin{array}{c}67 \\
- \\
-\end{array}$ & $\begin{array}{c}0.248 \\
- \\
-\end{array}$ & $\begin{array}{l}0.325 \\
0.273 \\
0.291\end{array}$ \\
\hline & & 88 & 552 & 14 & & \\
\hline \multirow[t]{2}{*}{$\begin{array}{l}43 \\
44 \\
45\end{array}$} & $\begin{array}{l}6 \\
6 \\
6\end{array}$ & $\begin{array}{l}137 \\
144 \\
113\end{array}$ & $\begin{array}{l}69 \\
74 \\
92\end{array}$ & $\begin{array}{l}67 \\
66 \\
55\end{array}$ & $\begin{array}{l}0.280 \\
0.266 \\
0.234\end{array}$ & $\begin{array}{l}0.306 \\
0.322 \\
0.286\end{array}$ \\
\hline & & 394 & 235 & 63 & & \\
\hline \multirow[t]{2}{*}{$\begin{array}{l}54 \\
55\end{array}$} & $\begin{array}{l}14 \\
14\end{array}$ & $\begin{array}{l}164 \\
202\end{array}$ & $\begin{array}{r}74 \\
115\end{array}$ & $\begin{array}{l}69 \\
64\end{array}$ & $\begin{array}{l}0.221 \\
0.269\end{array}$ & $\begin{array}{l}0.274 \\
0.286\end{array}$ \\
\hline & & 366 & 189 & 66 & & \\
\hline
\end{tabular}

followed by a reduction in their number as they become absorbed into the ovarian stroma.

There is no discernible difference in the histological appearance of the uterus of the immature guinea-pig up to 35 days after hypophysectomy.

\section{Serum gonadotrophin}

\section{EFFECTS OF GONADOTROPHINS}

This hormone was injected in varying amounts and at different intervals after hypophysectomy, as shown in Table 3. The initial test was made to 
observe the effect of a wide range of doses given on what was considered to be a fully regressed ovary, namely on the 14th day after operation. A dose of 25 i.u. restored the weight of the ovaries to that of unoperated animals and a dose of 50 i.u. or more brought about an increase in ovarian weight but did not restore the histological condition seen before hypophysectomy. There was no follicular growth beyond that seen in untreated animals 14 days after hypophysectomy, and the number of follicles that developed antra was not apparently increased. The quantitative effect was caused chiefly by the hypertrophy of the cells of the theca interna and, particularly, of the stromal tissues throughout the ovary. This tissue appears to be derived mainly from the thecal investment of follicles after their atresia; it somewhat resembles the 'interstitial tissue' of the ovary of the rat. The theca of many of the follicles of

TABLE 3

OVARIAN RESPONSE OF INDIVIDUAL ANIMALS TO VARYING AMOUNTS OF PMS GIVEN AS A SINGLE INJECTION AT DIFFERENT TIMES AFTER HYPOPHYSECTOMY

\begin{tabular}{|c|c|c|c|c|}
\hline \multirow{2}{*}{$\begin{array}{l}\text { Dose of PMS } \\
\quad(\text { i.u. })\end{array}$} & \multicolumn{4}{|c|}{$\begin{array}{c}\text { Weight of ovaries (mg) of guinea-pigs injected at } \\
\text { different times after hypophysectomy }\end{array}$} \\
\hline & 0 days & 2 days & 5 days & 14 days \\
\hline $\begin{array}{l}0 \\
6 \cdot 25 \\
12 \cdot 5 \\
25 \cdot 0\end{array}$ & $\begin{array}{l}48(4) \\
\\
34(2) \\
31(2)\end{array}$ & $43(4)$ & $\begin{array}{l}26(7) \\
27 \\
30\end{array}$ & $\begin{array}{l}30(2) \\
22 \\
22 \\
38\end{array}$ \\
\hline 50 & $\begin{array}{l}35 \\
30 \\
32\end{array}$ & $\begin{array}{l}34 \\
36\end{array}$ & $\begin{array}{l}43 \\
36\end{array}$ & 45 \\
\hline 100 & $\begin{array}{l}83 \\
52 \\
67\end{array}$ & $\begin{array}{r}119 \\
79\end{array}$ & $\begin{array}{l}71 \\
67 \\
72\end{array}$ & 66 \\
\hline 200 & 57 & $\begin{array}{l}58 \\
78 \\
54\end{array}$ & 132 & $\begin{array}{r}185 \\
88\end{array}$ \\
\hline
\end{tabular}

When more than one animal reccived similar treatment, the average ovarian weight is recorded and the number of animals is given in parentheses.

the guinea-pigs which received 50 or 100 i.u. PMs 14 days after hypophysectomy is indistinguishable from the surrounding stroma.

There were nearly 300 follicles with antra in the ovaries of the animal which received 100 i.u. on the 14th day after hypophysectomy; the largest of these was 400 to $450 \mu$ in diameter. Allowing for the slight hypertrophy of the theca interna, the development of these follicles corresponds approximately to that of normal follicles 350 to $400 \mu$ in diameter. They are thus very similar in number and in size to those of the untreated animal 14 days after hypophysectomy. Few of these vesicular follicles were atretic, as judged by the criteria applied to the untreated animals (see above) and the majority contained what appeared to be normal oocytes.

In further experiments the interval between operation and injection was 
progressively reduced as it became clear that the quantitative response of the guinea-pig to PMS was not predominantly one of follicular stimulation. It may be seen in Table 3 that the injection of $25 \mathrm{i}$.u. on the day of operation or of 50 i.u. on the 2nd day afterwards failed to maintain pre-operative ovarian weight. If these results are compared with the response produced by similar doses given on the 14th day after operation, it may be suggested that the guinea-pig ovary is more sensitive to stimulation the longer the injection is delayed after operation. At all times, the effect, as seen histologically, comprises in the main the stromal reaction described above.

A dose of $100 \mathrm{i}$.u. or more given on the day of hypophysectomy, or such a dose followed by a supplementary dose 5 days later, usually resulted in the formation of large numbers of large follicles with somewhat dispersed granulosa cells. These large follicles all appeared to be undergoing atresia; the condition of the granulosa was often difficult to assess but the oocyte was invariably abnormal and usually without chromatin material. In some cases the luteinizing

TABLE 4

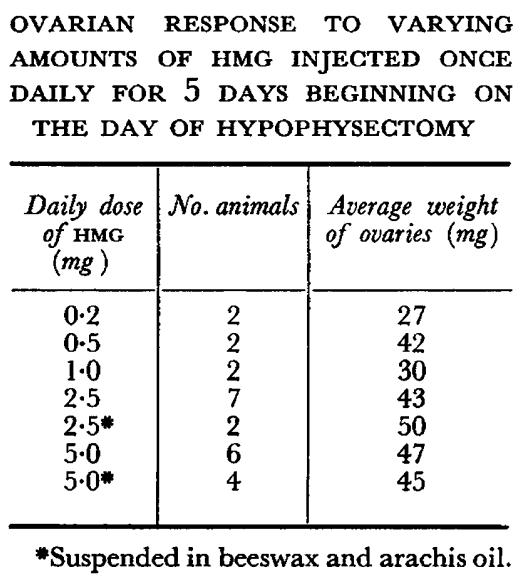

effect resulted in the formation of luteal cysts, with a degenerate oocyte retained within a sphere of 'luteal' tissue with quite well-defined boundaries and a central core of loose fibrous tissue. It is impossible to determine whether the granulosa was involved in the formation of these structures; it was destroyed in the atresia of the follicles which degenerated without forming such cysts.

\section{Human menopausal gonadotrophin}

In a preliminary test, three hypophysectomized guinea-pigs were injected daily with $0.2,1.0$ and $5.0 \mathrm{mg}$ of HMG for 5 days beginning on the 2nd day after operation. As no quantitative or histological response was elicited in the ovaries of these animals, further tests were begun on other guinea-pigs on the day of operation and the results are summarized in Table 4. These show that no obvious increase in ovarian weight was caused by any of the doses; a much less pronounced stromal reaction was evoked than with PMS, and there was little evidence of follicle stimulation. The ovaries of the animals that had received 
$5 \mathrm{mg}$ of this preparation daily contained no normal vesicular follicles, but in some there was a single greatly enlarged follicle with a degenerating oocyte (the nucleus contained no chromatin) or a large luteal cyst similar to those induced by large doses of PMs. The injection of $2.5 \mathrm{mg}$ and $5 \mathrm{mg}$ of HMG, suspended in beeswax and arachis oil to retard the rate of absorption of the hormone, did not vary the ovarian response in any perceptible way. The intravenous injection of $\mathrm{CG}$ after 5 days treatment with 2.5 or $5.0 \mathrm{mg}$ of HMG failed to induce ovulation.

\section{Other gonadotrophins}

The results obtained with other gonadotrophic extracts are shown in Table 5. A daily dose of $0.1 \mathrm{mg}$ of sheep pituitary extract, beginning after an interval of 1 week after hypophysectomy, failed to increase ovarian weight and caused no

TABLE 5

OVARIAN RESPONSE OF INDIVIDUAL ANIMALS TO VARIOUS GONADOTROPHIC PREPARATIONS INJEGTED ONCE DAILY FOR 5 DAYS BEGINNING AT DIFFERENT TIMES AFTER HYPOPHYSEGTOMY

\begin{tabular}{l|c|c|c}
\hline $\begin{array}{c}\text { Pituitary } \\
\text { preparation }\end{array}$ & $\begin{array}{c}\text { Time of first injec- } \\
\text { tion (days after } \\
\text { hypophysectomy) }\end{array}$ & $\begin{array}{c}\text { Daily dose } \\
(\mathrm{mg})\end{array}$ & $\begin{array}{c}\text { Ovarian weights } \\
(\mathrm{mg})\end{array}$ \\
\hline Sheep & 7 & $0 \cdot 1$ & $19,19,21$ \\
Horse & 9 & $1 \cdot 0$ & 28 \\
& & $2 \cdot 0$ & 33 \\
Human (CP 1) & 0 & $5 \cdot 0$ & $44,53^{*}$ \\
& 0 & $2 \cdot 5$ & $37,120^{*}$ \\
Guinea-pig & 0 & $10 \cdot 0$ & 39 \\
& & $50 \cdot 0$ & 46 \\
& & $5 \cdot 0 \dagger$ & 64 \\
& & $8 \cdot 0^{\ddagger}$ & 39,39 \\
\hline
\end{tabular}

" 'McShan' preparation (see p. 395).

$\dagger$ Pituitaries from hysterectomized guinea-pigs.

\$ Pituitaries from male guinea-pigs.

stromal reaction, but it appeared to extend the incidence of follicular atresia. No further tests were carried out with this preparation.

Considerably larger quantities ( 1 to $5 \mathrm{mg}$ ) of both extracts of horse pituitary (see p. 395) were used and an increase in ovarian weight was produced, which resulted from a stromal reaction, but without any clear-cut follicle stimulation. The largest dose led to the formation of luteal cysts and increased atresia.

Human pituitary extract, given daily from the day of operation, caused an increase in ovarian weight with the formation of luteal cysts. In one animal (HYG/205) there were many medium-sized follicles, but each contained a degenerate oocyte.

The pituitary homogenate prepared from male guinea-pigs caused an increase in ovarian weight in the two animals that received it. A smaller dose of a similar preparation from hysterectomized guinea-pigs, was given to one animal but 
had no effect. Such effect as was observed in these three animals was similar to that caused by the human pituitary extract (above).

\section{DISCUSSION}

The effect of hypophysectomy is to increase the proportion of follicles which undergo atresia, to such an extent that all the vesicular follicles are affected together with many smaller ones. Our counts and measurements of ovarian follicles at successive intervals after hypophysectomy of the immature guineapig confirm the conclusion which Dempsey (1937) reached with regard to the adult animal, namely that follicular growth, up to and including the early stages of antrum formation, is independent of the pituitary gland. That this was the case in the rat had already been shown by Smith (1930).

The refractoriness of the Graafian follicles in the hypophysectomized guineapig to stimulation by exogenous gonadotrophins, seen in this work, is in marked contrast to the responsiveness of the follicles of the hypophysectomized rat. This characteristic of the rat ovary has been widely used as a means of investigating qualitative differences in the hormonal nature of gonadotrophic preparations (see Noble, Rowlands, Warwick \& Williams, 1939; Rowlands \& Williams, 1940/41). The ovarian response in hypophysectomized guinea-pigs that has been found to occur almost consistently to all gonadotrophins that were tested is the so-called stromal reaction. A similar reaction has been described (Rowlands \& Williams, 1940/41) in the hypophysectomized rat, where it was elicited in response to doses of PMS which were insufficient to induce follicular growth; it was comparable with that induced by CG.

Hamburger \& Pedersen-Bjergaard (1946) concentrated on quantitative measurements applicable to gonadotrophin assay and emphasized the change of response which they observed in uterine weight and ovarian histology of intact immature guinea-pigs, with increasing dosage of gonadotrophin. We have not observed a reduction in uterine weight response with increasing dosage in hypophysectomized immature guinea-pigs, and we have not been able to find a preparation which would, at any given dose level, consistently produce mature follicles capable of ovulation and the formation of normal corpora lutea. Guyénot and co-workers were particularly concerned with the distinction between 'auxogenic' (follicle-stimulating) and 'crinogenic' (luteinizing) fractions of gonadotrophin, tested in hypophysectomized guinea-pigs (see Introduction). Our concern has been to attempt to induce an ovarian response sufficiently 'physiological' to permit the establishment of an ovarian cycle in the absence of the anterior pituitary gland. The Swiss workers did not report such a response to any of the preparations they employed, although they found a purely 'auxogenic' response to UFO (HMG) after hypophysectomy (Guyénot et al., 1939). In seven out of twelve completely hypophysectomized animals treated with varying amounts of this preparation for 6 to 13 days, beginning 3 to 85 days after operation, they obtained a purely follicle-stimulating effect, without any luteinization. Their photographs show the ovaries to contain many large follicles, presenting a very different appearance from any obtained by us. Three of the remaining animals, however, did not respond, and the other three showed some degree of luteiniza- 
tion. In two animals in which hypophysectomy was found to have been incomplete, the luteinizing response was considerable. In contrast, we have found a luteinizing effect in all cases, great care having been taken to exclude incompletely hypophysectomized animals. It seems unlikely, but it is not impossible, that this difference is due to the fact that Guyénot et al. (1939) used an extract from the urine of ovariectomized women, whereas we used HMG and other preparations.

Schmidt (1937) reported complete follicular development, ovulation, and corpus luteum formation, in intact immature guinea-pigs into which one or two pituitary glands from adult males had been implanted. The response was less marked when glands from females were used. Nelson (1935) had previously shown that the pituitary gland of the male guinea-pig contains twice as much gonadotrophin as does that of the female. In our experiments, an extract of whole pituitaries from male guinea-pigs when injected subcutaneously, yielded a slight follicle-stimulating effect which was no greater than that produced by a similar extract from female guinea-pigs. Both extracts produced stromal and thecal luteinization, characteristic of the 'crinogenic' effect found in intact guinea-pigs by Guyénot \& Held (1941).

\section{ACKNOWLEDGMENTS}

The authors express their gratitude to Dr W. M. Brownlie of Boots Pure Drug Co, Thurgaston, Notts, for a generous donation of freeze-dried PMs, and to Drs G. E. Adams, W. R. Butt and R. V. Short for samples of other gonadotrophins. The skilled technical assistance given by Miss G. H. Needham is gratefully acknowledged.

\section{REFERENCES}

Aron, M. (1932) L'hormone préhypophysaire excito-sécrétice des glandes endocrines génitales (gonadostimuline): Contribution à l'étude histophysiologique de l'ovaire et du testicule. Arch. Anat., Strasbourg, 15, 237.

Brooks, R. V., Clayton, B. E. \& Worden, J. M. (1959) The effect of oestradiol on the response of hypophysectomized guinea-pigs to adrenocorticotrophin. F. Endocrin. 19, 214.

Butt, W. R., Crooke, A. C., Cunningham, F. J. \& Wolf, A. (1963) Biological and immunological properties of human pituitary follicle stimulating hormone obtained by starch gel electrophoresis. 7. Endocrin. 25, 541 .

Dempsey, E. W. (1937) Follicular growth rate and ovulation after various experimental procedures in the guinea-pig. Amer. F. Physiol. 120, 126.

Freed, S. C. \& Coppack, A. (1936) Fundamental similarity in the development of gonadotrophic response in the immature guinea-pig and rat. Endocrinology, 20,81.

Good, 'T. A., Ely, R. S., Heiselt, L. R., Done, A. K. \& Kelley, V. C. (1956) Studies of 17 hydroxycorticosteroids: adrenalectomy and hypophysectomy in guinea-pigs and their effects on plasma 17-OHCS concentrations. Endocrinology, 58, 651.

Guyénot, E. \& Held, E. (1941) Action de l'urine de femme enceinte (UFE) sur femelles de cobayes hypophysectomisées. Rev. suisse Zool. 48, 377.

Guyénot, E., Held, E. \& Ponse, K. (1939) Action auxogène pure d'une urine de femme ovariotomisée (UFo). II. L'hypophysectomie du cobaye et du rat et l'action gonadotrope de l'urine de femme ovariotomisée (UFO). Arch. Anat., Strasbourg, 26, 289.

Hamburger, G. \& Pederson-Bjergaard, K. (1946) On the effect of gonadotrophins in normal infantile female guinea-pigs. Acta path. microbiol. scand. 23, 84 .

LOEB, L. (1932) The specificity in the action of the anterior pituitary of different mammals as well as of urine of pregnant women on the sex organs and thyroid glands of immature female guinea-pigs. Endocrinology, 16, 129.

$\mathrm{C}^{*}$ 
McPhall, M. K. \& Parkes, A. S. (1933) The adaptation of parapharyngeal hypophysectomy to the guinea-pig and hedgehog. Proc. roy. Soc. B, 114, 10.

Nexson, W. O. (1935) Changes in the hypophyses of castrated and cryptorchid guinea-pigs. Proc. Soc. exp. Biol., N.Y. 32, 1605.

Noble, R. L., Rowlands, I. W., Warwick, M. H. \& Williams, P. G. (1939) Comparative effects of certain gonadotrophic extracts on the ovaries of normal and hypophysectomized rats. $\mathcal{J}$. Endocrin. 1, 22.

Rowland, I. W. (1961) Effect of hysterectomy at different stages in the life cycle of the corpus luteum in the guinea-pig. 7. Reprod. Fertil. 2, 341.

Rowlands, I. W. \& Williams, P. C. (1940/41) Comparative activity of the gonadotrophin on horse pituitary glands and in pregnant mares' serum. F. Endocrin. 2, 380.

Schmm, I. G. (1937) The effects of hypophyseal implants from normal mature guinea-pigs on the sex organs of immature guinea-pigs. Endocrinology, 21, 461.

Sмrтн, P. E. (1930) Hypophysectomy and a replacement therapy in the rat. Amer. J. Anat. 45, 205.

Stafford, W. T., Collins, R. F. \& Mossman, H. W. (1942) The thecal gland in the guinea-pig ovary. Anat. Rec. 83, 193. 